

\title{
Revista Ciencia Multidisciplinaria CUNORI http://revistacunori.com
}

DOI: https://doi.org/10.36314/cunori.v2i1.64

ISSN: 2617- 474X (impresa) / 2617- 4758 (en línea)

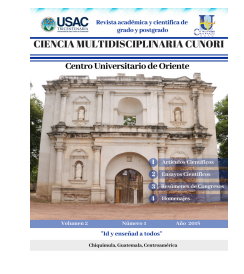

\section{P7 - Memorias del exilio salvadoreño en México, 1975 - 2002}

\section{Memoirs of the Salvadoran exile in Mexico, 1975 - 2002}

\author{
Elena María Salamanca Martínez*, María Teresa Mosquera \\ El Colegio de México, México* \\ ${ }^{2}$ Instituto de Estudios Interétnicos-USAC
}

*Autor para correspondencia.

Correo electrónico: esalamanca@colmex.mx

\section{Resumen}

$\mathrm{E}$ 1 acercamiento al exilio salvadoreño es complejo, pues obedece a una serie de momentos en los que los salvadoreños pidieron refugio en México -y otros países- a lo largo del siglo XX que aún no han sido abordados dentro de la historiografía nacional. México ha sido receptor de salvadoreños que huían para poner a salvo sus vidas en dos contextos políticos paradigmáticos: durante la presidencia del general Maximiliano Hernández Martínez (1931 a 1944), y durante la guerra civil (1980 y 1992). Este trabajo aborda el asilo político conseguido por salvadoreños antes del periodo conocido como guerra civil (1975) y hasta la firma de los acuerdos de paz (1972); en este período al menos un cuarto de millón de salvadoreños recibió el asilo político en México. Se aborda el exilio en la memoria de sus protagonistas, a partir de la historia oral recabada por el archivo de la memoria del exilio latinoamericano en México, y luego ofrezco una valoración de la memoria sobre el exilio en la memoria y la historiografía salvadoreña después de la firma de los Acuerdos de paz de 1992. La experiencia de los exiliados está cargada de singularidades: cultura, cotidianidad, solidaridad política y los factores económicos moldearon los diversos exilios. La transición de la guerra a la paz no significó el regreso para los exiliados. Algunos volvieron al país de origen por breve tiempo y empezaron otros procesos migratorios, ya que los exiliados no eran parte del modelo nacional ni del lenguaje político.

Palabras clave: exilio, memoria, historiografía, historial oral

\section{Abstract}

$\mathrm{T}$ The approach to Salvadoran exile is complex, since it obeys a series of moments in which Salvadorans sought refuge in Mexico -

and other countries - throughout the twentieth century that have not yet been addressed within national historiography. Mexico has been a recipient of Salvadorans who fled to save their lives in two paradigmatic political contexts: during the presidency of General Maximiliano Hernández Martínez (1931 to 1944), and during the civil war (1980 and 1992). This paper addresses the political asylum achieved by Salvadorans before the period known as civil war (1975) and until the signing of the Peace Accords (1972); In this period, at least a quarter of a million Salvadorans received political asylum in Mexico. Exile is addressed in the memory of its protagonists, from the oral history gathered by the Archive of the Memory of the Latin American Exile in Mexico, and then I offer an evaluation of the memory on the exile in the memory and the Salvadoran historiography after the signing of the 1992 Peace Accords. The experience of the exiles is full of singularities: culture, daily life, political solidarity and economic factors shaped the various exiles. The transition from war to peace did not mean a return for the exiles. Some returned to the country of origin for a short time and began other migratory processes, since the exiles were not part of the national model or the political language.

Keywords: exile, memory, historiography, oral history 


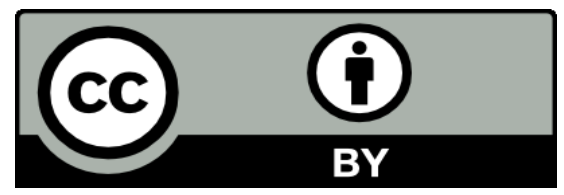

Este texto está protegido por una licencia CreativeCommons 4.0.

Usted es libre para compartir, copiar y redistribuir el material en cualquier medio o formato y adaptar el documento, remezclar, transformar y crear a partir del material para cualquier propósito, incluso comercialmente, siempre que cumpla la condición de atribución: usted debe reconocer el crédito de una obra de manera adecuada, proporcionar un enlace a la licencia, e indicar si se han realizado cambios. Puede hacerlo en cualquier forma razonable, pero no de forma tal que sugiera que tiene el apoyo del licenciante o lo recibe por el uso que hace. 